\title{
PEMBERIAN MOTIVASI DAN REWARD DENGAN KINERJA KARYAWAN
}

\author{
${ }^{1}$ Wanalia Wulan, ${ }^{2}$ Komara Nur Ikhsan, $\&{ }^{3}$ Adi Maladona \\ $1,2,3$ Dosen FIKes UNIGAL Ciamis.
}

\begin{abstract}
Abstrak
Penelitian ini bertujuan untuk mengetahui pemberian motivasi dan reward dengan kinerja perawat RSUD Kelas C Kabupaten Ciamis. Objek penelitian meliputi pemberian motivasi, reward dan kinerja perawat. Ketiga variabel dianalisis sesuai dengan ketentuan yang telah direncanakan. Metode penelitian menggunakan deskriptif analitis dengan pendekatan survey. Analisis menggunakan regresi linier sederhana. Hasil penelitian menunjukkan bahwa hubungan pemberian motivasi dan reward dengan kinerja perawat sebesar 0,993 dengan nilai $F=247,429$ taraf signifikansi 0,003 . Hasil penelitian diperoleh kesimpulan sebagai berikut; terdapat hubungan pemberian motivasi dengan kinerja perawat pada perawat rawat inap RSUD Kelas C Kabupaten Ciamis, hal ini berarti pemberian motivasi yang dilakukan oleh pihak RSUD Kelas C Kabupaten Ciamis dapat meningkatkan kinerja perawat namun tidak selamanya faktor pekerjaan yang menarik dapat memuaskan dalam bekerja. Terdapat hubungan pemberian reward dengan kinerja perawat pada perawat rawat inap RSUD Kelas C Kabupaten Ciamis, hal ini berarti reward yang diberikan pihak RSUD Kelas C Kabupaten Ciamis dapat memberikan kontribusi terhadap peningkatan kinerja karyawan namun kemampuan menciptakan peluang pekerjaan sesuai dengan fungsi dan tanggung jawab dalam perusahaan dapat meningkatkan kinerja perawat. Terdapat hubungan antara pemberian motivasi dan pemberian reward dengan kinerja perawat pada perawat RSUD Kelas C Kabupaten Ciamis namun selain pemberian motivasi dan reward kepribadian seseorang yang memiliki semangat untuk lebih baik dari orang lain merupakan salah satu faktor yang dapat meningkatkan kinerja perawat.
\end{abstract}

Kata Kunci : Motivasi, Reward, Perawat

\begin{abstract}
Research aim to to know; relation giving of motivation and of reward with performance nurse of RSUD class of $C$ sub-province of Ciamis. Object research cover giving of motivation, reward and performance nurse of RSUD Class of C Sub-Province of Ciamis. Third of the variable will be analysed pursuant to which have been planned. Research method use analytical descriptive method with approach of survey. Analyzer the used analysis of regresi linear modestly. Result of research indicate that relation giving of and motivation of reward with nurse performance equal to 0,993 with $F$ value equal to 247,429 with signifikansi 0,003. Result of research obtained the following conclusion; There are relation giving of motivation with nurse performance at nurse take care of to lodge RSUD Class of C Sub-Province of Ciamis, matter this means giving of motivation conducted by side of RSUD Class of C SubProvince of Ciamis can improve nurse performance but do not forever interesting work factor can gratify in working. There are relation giving of reward with nurse performance nurse take care of to lodge RSUD Class of C Sub-Province of Ciamis, matter this means given reward is side of RSUD Class of C Sub-Province of Ciamis can give contribution to make-up of employees performance but ability create opportunity of work as according to responsibility and function in company can improve nurse performance. There are relation between giving of motivation and giving of reward with nurse performance nurse of RSUD Class of C SubProvince of Ciamis but besides giving of and motivation of reward personality of someone owning the spirit to be more either from others represent one of factor able to improve nurse performance.
\end{abstract}

Keyword : Motivation, Reward, Nurse. 


\section{PENDAHULUAN}

Rumah sakit sebagai salah satu fasilitas pelayanan kesehatan memiliki peran yang sangat strategis dalam upaya mempercepat peningkatan derajat kesehatan masyarakat Indonesia. Salah satu profesi yang mempunyai peran penting di rumah sakit adalah perawat. Keperawatan adalah salah satu profesi di rumah sakit yang berperan penting dalam penyelenggaraan upaya menjaga mutu pelayanan kesehatan di rumah sakit. Pada standar tentang evaluasi dan pengendalian mutu dijelaskan bahwa pelayanan keperawatan menjamin adanya asuhan keperawatan yang bermutu tinggi dengan terus menerus melibatkan diri dalam program pengendalianmutu di rumah sakit (Tjandra Yoga, 2004)

Perawat merupakan sumber daya manusia terpenting di rumah sakit karena selain jumlahnya yang dominan (55-65\%) juga merupakan profesi yang memberikan pelayanan yang konstan dan terus meneru selama 24 jam kepada pasien setiap hari. Oleh karena itu pelayanan keperawatan sebagai bagian integral dari pelayanan kesehatan jelas mempunyai kontribusi yang sangat menentukan kualitas pelayanan di rumah sakit. Sehingga setiap upaya unyuk meningkatkan kualitas pelayanan rumah sakit harus juga disertai upaya untuk meningkatkan kualitas pelayanan keperawatan. (Yani, 2007)

Menurut Anwar Prabu, (2001) kinerja adalah hasil kerja secara kualitas dan kuantitas yang dicapai oleh seorang karyawan dalam melaksanakan tugasnya sesuai dengan tanggung jawab yang diberikan kepadanya. Faktor yang mempengaruhi pencapaian kinerja terdiri atas beberapa faktor, diantaranya yaitu motivasi kerja. Motivasi pada dasarnya adalah proses untuk mencoba mempengaruhi seseorang agar melakukan yang kita inginkan. Dengan kata lain adalah dorongan dari luar terhadap seseorang agar mau melaksanakan sesuatu. Dengan dorongan (driving force) disini dimaksudkan desakan yang alami untuk memuaskan kebutuhan-kebutuhan hidup, dan kecendrungan untuk mempertahankan hidup. Kunci yang terpenting untuk itu tak lain adalah pengertian yang mendalam tentang manusia.

Sebagai langkah nyata dalam hasil pembinaan maka diadakan pemberian penghargaan pegawai yang telah menunjukkan prestasi kerja yang baik. Adapun pengertian dari penghargaan dalam perusahaan kerap dalam bentuk pemberian berupa piagam dan sejumlah uang dari perusahaan pegawai yang mempunyai prestasi. Ada juga perusahaan yang memberikan penghargaan kepada pegawai karena masa kerja dan pengabdiannya dapat dijadikan teladan bagi pegawai lainnya. Pemberian penghargaan karena masa kerja pegawai bertujuan untuk memotivasi gairah dan loyalitas perusahaan. Pemberian penghargaan tersebut merupakan upaya perusahaan dalam memberikan balas jasa atas hasil kerja pegawai, sehingga dapat mendorong pegawai bekerja lebih giat dan berpotensi. Pegawai memerlukan suatu penghargaan pada saat hasil kerjanya telah memenuhi atau bahkan melebihi standar yang telah ditentukan oleh perusahaan. Penghargaan ini dapat berupa pujian. Tidak hanya kalau pegawai melakukan kesalahan memperoleh makian dari pimpinan. Pegawai bekerja mempunyai tujuan, antara lain untuk memperoleh penghasilan agar kebutuhan dan keinginannya dapat direalisasikan.

\section{METODOLOGI PENELITIAN}

Metode yang digunakan dalam penelitian ini adalah metode deskriptif analitis dengan pendekatan survey. Metode deskriptif analisis adalah suatu metode yang meneliti status kelompok manusia, objek, suatu set kondisi, suatu sistem pemikiran, ataupun suatu kelas peristiwa pada masa sekarang dengan tujuan membuat deskripsi, gambaran atau 
lukisan sistematis, faktual dan akurat mengenai fakta-fakta, sifat, serta hubungan antara fenomena yang diselidiki. (Nazir, 2005).

Variabel dalam penelitian ini terdiri dari variabel bebas (independent variabel) yaitu pemberian motivasi, Variabel terikat (dependent variabel) adalah kinerja perawat. Populasi sasaran (target population) adalah perawat rawat inap RSUD kelas C Kabupaten Ciamis. Karena teknik sampling atau penarikan sampel yang digunakan adalah non probability sampling yang merupakan teknik pengambilan sampel yang tidak memberikan peluang sama untuk dipilih menjadi sampel, untuk itu pengambilan sampel ini penulis menggunakan metode total sampling.

\section{HASIL PENELITIAN}

Pemberian Motivasi dengan Kinerja Perawat

Mengetahui hubungan pemberian motivasi dengan kinerja perawat pada perawat rawat inap RSUD kelas C kabupaten Ciamis, maka dilakukan uji atas hipotesis. Dimana hipotesis tersebut sebagai berikut : "terdapat hubungan yang bermakna pemberian motivasi dengan kinerja perawat", yang berarti bahwa pemberian motivasi yang baik akan menyebabkan kinerja perawat yang baik pula dan begitupun sebaliknya.

Menguji hipotesis hubungan pemberian motivasi dengan dilakukan uji t, dari hasil analisis perhitungan SPSS diperoleh $t_{\text {hitung }}$ sebesar 5,208 dan dari tabel distribusi $\mathrm{t}$ dengan $\mathrm{dk}=10$ pada tingkat keyakinan 95\% $\alpha=0,05$ diperoleh $\mathrm{t}_{\text {tabel }}$ sebesar 2,228. Maka dengan pengujian dua arah, menunjukkan bahwa nilai $\mathrm{t}_{\text {hitung }}(5,208)>\mathrm{t}_{\text {tabel }}(2,228)$, berarti bahwa terdapat hubungan yang signifikan antara pemberian motivasi dengan kinerja perawat pada perawatrawatinap RSUD kelas $\mathrm{C}$ kabipatenCiamis.
Pemberian Reward dengan Kinerja

Perawat

Mengetahui hubungan pemberian reward dengan kinerja perawat pada perawatrawatinap RSUD kelas $\mathrm{C}$ KabupatenCiamis, maka dilakukan uji atas hipotesis. Dimana hipotesis tersebut sebagai berikut: "terdapat hubungan yang bermakna pemberian reward dengan kinerja perawat", yang berarti bahwa pemberian reward yang baik akan menyebabkan kinerja perawat yang baik pula dan begitupun sebaliknya.

Menguji hipotesis hubungan pemberian reward dengan dilakukan uji t, dari hasil analisis perhitungan SPSS diperoleh $t_{\text {hitung }}$ sebesar 4,587 dan dari tabel distribusi $\mathrm{t}$ dengan $\mathrm{dk}=10$ pada tingkat keyakinan 95\% $\alpha=0,05$ diperoleh $\mathrm{t}_{\text {tabel }}$ sebesar 2,228. Maka dengan pengujian dua arah, menunjukkan bahwa nilai $\mathrm{t}_{\text {hitung }}(4,587)>\mathrm{t}_{\text {tabel }}(2,228)$, berarti bahwa terdapat hubungan yang signifikan antara pemberian reward dengan kinerja perawatpadaperawatrawatinap RSUD kelas C KabupatenCiamis

Pemberian Motivasi dan Pemberian Reward dengan Kinerja Perawat

Mengetahui kuat lemahnya hubungan pemberian motivasi dan pemberian reward dengan kinerja perawat pada perawatrawatinap RSUD kelas C KabupatenCiamismenggunakan analisis data yang meliputi analisis regresi berganda, analisis koefisien korelasi dan koefisien determinasi dengan menggunakan program komputer.

Mengetahui hubungan pemberian motivasi dan pemberian reward dengan kinerja perawatsecara simultan, maka dilakukan uji hipotesis. Dimana hipotesis yang diajukan adalah : "terdapat hubungan yang signifikan antara pemberian motivasi dan pemberian reward dengan kinerja perawat", yang berarti bila pemberian motivasi dan pemberian reward baik maka kinerja perawat akan meningkat. 
Berdasarkan hasil pengolahan data diperoleh suatu persamaan regresi berganda yang menunjukkan hubungan antara pemberian motivasi $\left(\mathrm{X}_{1}\right)$, pemberian reward $\left(\mathrm{X}_{2}\right)$, dan kinerja perawat $(\mathrm{Y})$ sebagai berikut :

$Y=15,981+(0,263) X_{1}+(0,290) X_{2}$

Dari persamaan tersebut dapat diperoleh sebagai berikut: $a=15,981$, $\mathrm{b}_{1}=0,263, \mathrm{~b}_{2}=0,290$. Nilai konstanta (a) sebesar 15,981 menunjukkan tingkat kinerja perawatyang dicapai yaitu sebesar 15,981 pada saat pemberian motivasi dan pemberian reward bernilai nol (0). Sedangkan untuk nilai $b_{1}$ sebesar 0,263 menunjukkan setiap pemberian motivasi sebesar 1 kali lebih baik akan berakibat penambahan sebesar 0,263 pada kinerja karyawan, dengan asumsi variabel lain diabaikan. Hal ini dikarenakan dengan adanya pemberian motivasi maka dapat meningkatkan kinerja perawat. Nilai $b_{2}$ sebesar 0,290 menunjukkan bahwa setiap perubahan pemberian reward 1 kali akan mengakibatkan penambahan sebesar 0,290 pada kinerja karyawan yang dicapai, dengan asumsi variabel lain diabaikan. Hal ini dikarenakan dengan adanya pemberian reward maka perusahaan dapat meningkatkan kinerja perawat. Dengan demikian dapat diartikan bahwa persamaan regresi ini dapat digunakan untuk memprediksi bagaimana kinerja perawatakan terjadi apabila faktorfaktornya telah ditentukan.

Analisis ini digunakan untuk mengetahui kekuatan hubungan antar variabel-variabel yang diteliti. Berdasarkan hasil perhitungan SPSS diperoleh nilai $R$ sebesar 0,993. Nilai tersebut dapat diinterpretasikan bahwa pemberian motivasi dan pemberian reward dengan kinerja perawatmempunyai hubungan positif atau searah dengan derajat keeratan termasuk kategori sangat kuat karena berada di antara 0,80-0,999. Hal ini berarti jika pemberian motivasi dan pemberian reward naik atau bertambah maka kinerja karyawan pun akan mengalami kenaikan, demikian sebaliknya jika pemberian motivasi dan pemberian reward menurun maka kinerja perawatakan mengalami penurunan.

Menguji hipotesis hubungan pemberian motivasi dan pemberian reward dengan kinerja perawatdilakukan uji $F$, dari hasil analisis perhitungan program komputer diperoleh $\mathrm{F}_{\text {hitung }}$ sebesar 247,429 dan dari tabel distribusi $\mathrm{F}$ dengan $\mathrm{dk}$ penyebut $=10 \mathrm{dan} \mathrm{dk}$ pembilang $=2$ pada tingkat keyakinan 95\% $\alpha=0,05$ maka diperoleh $\mathrm{F}_{\text {tabel }}$ sebesar 4,26. Hal ini menunjukkan bahwa $F_{\text {hitung }}(247,429)>F$ tabel $(4,26)$, yang berarti terdapat hubungan yang signifikan antara pemberian motivasi dan pemberian reward dengan kinerja perawat. Hal ini menunjukkan bahwa setiap terjadi perubahan atas pemberian motivasi dan pemberian reward maka dapat mengakibatkan perubahan pada kinerja perawatyang dicapai.

\section{PEMBAHASAN}

Motivasi merupakan serangkaian sikap dan nilai-nilai yang mempengaruhi individu untuk mencapai hal yang spesifik sesuai dengan tujuan individu. Sikap dan nilai tersebut merupakan suatu kekuatan untuk mendorong individu bertingkah laku dalam mencapai tujuan. Dorongan tersebut terdiri dari dua komponen, yaitu: arah perilaku kerja (kerja untuk mencapai tujuan), dan kekuatan perilaku (sebagai kuat usaha individu dalam bekerja). Motivasi meliputi perasaan unik, pikiran dan pengalaman masa lalu yang merupakan bagian dari hubungan internal dan eksternal perusahaan.

Motivasi jika dihubungkan dengan hirarki kebutuhan manusia, maka menyangkut kebutuhan tingkat lebih tinggi (higher level needs) yaitu esteem needs dan self actualization needs. Nilai kerja 
meliputi ketertarikan terhadap pekerjaan, tertantang pada pekerjaan, belajar hal baru, membuat kontribusi penting, memanfaatkan potensi kerja sepenuhnya, tanggung jawab, otonomi dan kreatif. Motivasi intrinsik ada untuk posisi ketertarikan dan ketertantangan dalam pekerjaan.

Pemberian reward merupakan motivasi ekstrinsik adalah motivasi yang ada kaitannya dengan imbalan yang diterima seseorang sesudah melakukan pekerjaan. Imbalan ini dapat berupa promosi, hubungan pribadi, gaji, upah, serta tunjangan, sehingga motivasi ekstrinsik ini berasal dari luar pribadi atau individu.

Berdasarkan hasil penelitian yang telah dilakukan mengenai hubungan pemberian motivasi dan pemberian reward dengan kinerja perawat pada perawatrawatinap RSUD kelas C KabupatenCiamis diperoleh hasil bahwa terdapat hubungan antara pemberian motivasi dan pemberian reward dengan kinerja perawat hal ini terbukti bahwa hasil analisis perhitungan program komputer diperoleh $\mathrm{F}_{\text {hitung }}$ sebesar 247,429 dan dari tabel distribusi $\mathrm{F}$ dengan $\mathrm{dk}$ penyebut $=10$ dan $\mathrm{dk}$ pembilang $=2$ pada tingkat keyakinan $95 \% \alpha=0,05$ maka diperoleh $\mathrm{F}$ tabel sebesar 4,26. Hal ini menunjukkan bahwa $F_{\text {hitung }}(247,429)>F_{\text {tabel }}(4,26)$, yang berarti terdapat hubungan yang signifikan antara pemberian motivasi dan pemberian reward dengan kinerja perawat.

Untuk meningkatkan motivasi dari teori ini adalah jelas untuk mengusahakan adanya keadilan yang dirasakan oleh pegawai. Ini dapat dilakukan dengan melakukan evaluasi jabatan dan melakukan survei gaji keluar. Kedua kegiatan ini dilakukan untuk mengusahakan terciptanya keadilan internal dan eksternal.

Menurut Manullang (2001) menyatakan bahwa jika perusahaan menyediakan kondisi-kondisi kerja, upah, tunjangan, atau keselamatan kerja yang tidak mencukupi, maka ia akan mendapat kesulitan dalam menarik karyawankaryawan yang baik, dan perputaran, kemangkiran serta keluhan-keluhan akan meningkat. Maka pemberian motivasi dan pemberian reward dapat mempengaruhi terhadap kinerja dari karyawan tersebut.

Hasil penelitian ini sejalan dengan Gomez (2003) Kemampuan melekat dalam diri seseorang dan merupakan bawaan sejak lahir serta diwujudkan dalam tindakannya dalam bekerja, sedangkan motivasi adalah aspek yang sangat penting untuk menggerakkan kreativitas dan kemampuan seseorang dalam melakukan suatu pekerjaan, serta selalu bersemangat dalam menjalankan pekerjaan tersebut.

Dengan demikian motivasi berfungsi untuk merangsang kemampuan karyawan maka akan tercipta hasil kinerja maksimal. perwujudan kinerja yang maksimal, dibutuhkan suatu dorongan untuk memunculkan kemauan dan semangat kerja, yaitu baik berupa motivasi maupun reward.

\section{KESIMPULAN}

Terdapat hubungan antara pemberian motivasi dengan kinerja perawat pada perawat rawat inap RSUD kelas $C$ Kabupaten Ciamis, hal ini berarti pemberian motivasi yang dilakukan oleh pihak RSUD kelas C Kabupaten Ciamis dapat meningkatkan kinerja karyawan namun tidak selamanya faktor pekerjaan yang menarik dapat memuaskan dalam bekerja.

Terdapat hubungan antara pemberian reward dengan kinerja perawat pada perawat rawat inap RSUD kelas C Kabupaten Ciamis, hal ini berarti reward yang diberikan pihak RSUD kelas $\mathrm{C}$ Kabupaten Ciamis dapat memberikan kontribusi terhadap peningkatan kinerja perawat namun kemampuan menciptakan peluang pekerjaan sesuai dengan fungsi dan tanggung jawab dalam perusahaan dapat meningkatkan kinerja perawat. 
Terdapat hubungan antara pemberian motivasi dan pemberian reward dengan kinerja perawat pada perawat rawat inap RSUD kelas C Kabupaten Ciamis namun selain pemberian motivasi dan reward, kepribadian seseorang yang memiliki semangat untuk lebih baik dari orang lain merupakan salah satu faktor yang dapat meningkatkan kinerja perawat.

\section{SARAN}

Berdasarkan pemberian motivasi, sebaiknya perusahaan dapat menciptakan suasana pekerjaan yang menarik dan tidak membosankan sehingga dapat memuaskan perawat dalam bekerja.

Berdasarkan pemberian reward, disarankan bagi perusahaan memberikan penilaian yang lebih bagi mereka yang berprestasi sehingga terjadi persaingan yang sehat antara perawat.

Berdasarkan kinerja perawat, disarankan bagi perusahaan untuk menciptakan peluang kerja lain sehingga karyawan tidak terfokus pada satu pekerjaan yang diangga dapat memberikan kelangsungan dalam bekerja.

\section{DAFTAR PUSTAKA}

Apriani, D. (2012). Pengaruh Motivasi Kepuasan Kerja, dan Disiplin Kerja terhadap Kinerja Karyawan. Jurnal Mahasiswa. Semarang : Universitas Semarang.

Dharma, A., (1985). Manajemen Prestasi Kerja. Cetekan Pertama. Jakarta : CV. Rajawali.

Enas, (2011). Metode Penelitian Elaborasi Pedoman Penulisan Tesis dan Disertasi. Cetakan Pertama. Bandung : Dewa Ruchi.

Hariandja, M.T.E., (2009). Manajemen Sumber Daya Manusia. Cetakan Kelima. Jakarta : PT. Grasindo.

Kasmir, (2002). Dasar-dasar Perbankan. Jakarta: PT. Rajagrafindo Persada.

Komarudin, (2008). Konsep reward dan punishment. http://sas.ilbn.info/gdl.php?mod= browse8op.com

Malayu S.P.H., (2007). Dasar-dasar Perbankan. Cetakan Keenam. Jakarta: Bumi Aksara.

Mangkunegara, A.P., (2011). Manajemen Sumber Daya Manusia Perusahaan. Cetakan Kesepuluh. Bandung : PT. Remaja Rosdakarya.

Mohammad, N., (2006). Metode Penelitian. Jakarta: Ghalia Indonesia.

Mudrajat, K., (2007). Metode Kuantitaf. Edisi ketiga. Yogyakarta: UPPSTIMYKPN.

Sekaran, U., (2006). Research Methods For Business. Edisi keempat. Jakarta: Salemba Empat.

Sinambela, L.P., (2012). Kinerja Pegawai. Cetakan Pertama. Yogyakarta : Graha IImu.

Subekhi. A,. (2012). Pengantar Manajemen Sumber Daya Manusia. Cetakan Pertama. Jakarta : Prestasi Pustaka.

Sugiyono, (2006). Metode Penelitian Bisinis. Cetakan Kesembilan. Bandung: CV. Alfabeta.

Suparman, (2007). Analisis Pengaruh Peran kepemimpinan, Motivasi, dan Komitmen Organisasi terhadap Kepuasan Kerja dalam Meningkatkan Kinerja Pegawai. Jurnal Tesis. Semarang : Universitas Dipenogoro. (2007). Statistik untuk Penelitian. Cetakan Keduabelas. Bandung: CV. Alfabeta. 